\title{
Debating Diversity in Management Accounting Research
}

\author{
John Burns \\ University of Exeter \\ K.J. Euske \\ Naval Postgraduate School \\ Mary A. Malina \\ University of Colorado Denver
}

April 2014 


\begin{abstract}
Anthony's 1972 paper in Sloan Management Review makes a call to academics to adjust the trajectory of management accounting research. This paper chronicles the evolution of the academic debate regarding that adjustment and discusses its impact on the current state of management accounting research. Our review of the literature reveals that early responses in the 1980's and 1990's to Anthony's call primarily came from United States (U.S.) academics that suggest a broader theoretical approach and more work in the field. After 2000, non-U.S. authors and non-U.S. journals take up the call for diversity and shift the discussion to the more fundamental topic of validating and accepting various research paradigms. The U.S. academic environment fosters a narrow yet important view of management account research. To balance the U.S. view, non-U.S. academics have the liberty of using diverse theories, paradigms, and methods. However, a challenge moving forward is for diverse research approaches to be valued and published in top accounting journals that tend to be U.S. based.
\end{abstract}




\section{Debating Diversity in Management Accounting Research}

\section{Introduction}

Anthony’s 1972 paper in Sloan Management Review makes a call to academics to adjust the trajectory of management accounting research. He argues that academic researchers: (1) are not making notable contributions to the social sciences, (2) need to branch away from economic theory to behavioral theories, and (3) need to keep a focus on what will be useful in the real world. Since this seminal paper, researchers continue to write papers calling for a broader approach to management accounting academic research. This paper chronicles the evolution of the academic debate on diversity in management accounting research and discusses its impact on the current state of management accounting research.

Our review of the literature reveals that early responses to Anthony's call primarily came from United States (U.S.) academics that concur with the need for a broader approach. They urge academics to move beyond traditional research approaches by getting out in the field, broadening theoretical foundations beyond economics, and focusing on impacting practice. After the calls for change were made in the 1970's, 1980's, and 1990's (mainly by U.S. authors in U.S. journals) we find that non-U.S. authors and non-U.S. journals begin to take up the call for diversity. The efforts of non-U.S. authors shifted the discussion to the more fundamental topic of validating and accepting various research paradigms.

\section{Chronological Discussion of Papers}

Our approach for looking back over more than forty years at the stream of research on diversity in management accounting began with some basic definitions. For the purposes of this paper, we define management accounting research as what is created, reported, and used inside the firm and generally not seen as part of the financial reporting process. Additionally, we define 
diversity in management accounting research as the available portfolio of methods, theories, and paradigms including their intended impact on both practice and research. We kept these definitions in mind when searching articles written since 1972 in which the diversity of management accounting was an important theme. We selected a set of journals that, from our professional experience, are most likely to publish papers on the diversity of academic management accounting research. While this approach might not produce an exhaustive list of journals, it is likely to capture the most notable articles written on the topic of diversity in management accounting.

For each article, we classified the author(s) and journal as either U.S. or non-U.S. The author classification was made based on the author affiliation at the time the article was published. Again, this approach might not produce a result that is totally without error in determining an author's training and influence, but it was a consistent method for creating our broad classifications. Journal affiliation was determined by the location of the school or association publishing the journal. We gathered this data because our experience is that an author's and journal's home country could impact the discussion of diversity.

Our search identified 73 papers written on diversity in management accounting research. Each of the papers included in our search are listed in appendix 1. Figure 1 presents the number of papers published by decade for U.S. versus non-U.S. authors. Figure 2 presents the number of papers published by decade for U.S. versus non-U.S. journals. As evidenced by both graphs, U.S. authors and journals dominate early discussions of diversity while non-U.S. authors and journals dominate more current discussions of diversity. The following section discusses the major themes of these diversity papers by decade, as well as details behind the trends noted in figures 1 and 2 . 
---Insert Figures 1 and 2 about here--

The 1980's. In the literature we reviewed, there was an 11-year lag between Anthony's paper in 1972 and the next papers published in 1983. Eight papers in our sample on the topic of diversity in management accounting research were published in the 1980's. Of the eight papers published during this decade, five were U.S. authored. Robert Kaplan was particularly active during this decade, penning three of the eight papers. U.S. based journals were the primary outlet, with two papers in The Accounting Review (TAR) and three in Journal of Management Accounting Research (JMAR). Accounting, Organizations and Society (AOS) was the only nonU.S. based journal in the set and published three papers.

The authors of the eight papers reiterate the need to broaden theoretical foundations beyond economics. They express concerns that agency theory is too simplified for the complicated settings of real organizations (Hopwood, 1983; Anthony, 1989; Horngren 1989) and urge future research to integrate other management disciplines and behavioral considerations. Authors in this decade also suggest that academic researchers get out of their offices and conduct research in the field (Kaplan, 1983, 1984, 1986; Horngren 1989; Shillinglaw 1989). They assert that management accounting researchers know little about what actually happens in management accounting practice. They suggest undertaking more research work in the field (i.e., case studies and field studies) to understand how accounting information is developed and used in organizations.

Two papers written in this decade also move beyond the themes of broadening of theory and field research. Hopper, Storey \& Wilmott (1987) suggest that academics should be aware of the shortcomings of the mainstream approach to research and be open to other views of reality. And, Shillinglaw (1989) introduces the notion that those who answer the call for diversity will 
face an uphill battle. He expresses concern that some journals will have to become willing to publish the results and that senior faculty will need to be persuaded to value the findings.

The 1990's. Eight papers in our sample were written on the topic of diversity in the 1990's. U.S. academics authored five of the eight papers and six of the eight papers appeared in U.S. based journals (four in Advances in Management Accounting (AIMA), two in JMAR). All eight papers continue the call for academic management accounting researchers to broaden their theoretical foundations and to conduct more research in the field.

The 2000's. The 2000's mark the busiest decade and begin the shift to non-U.S. authors and to non-U.S. journals. Additionally, this decade marks a change in the focus of components of diversity from theory, method, and impact on practice to the more broad research paradigms. U.S. authors wrote only ten of the 38 articles published in this decade. Of these 38 articles, only seven were published in U.S. journals (AIMA, Accounting Horizons (AH), Behavioral Research in Accounting (BRIA), JMAR, and Journal of Accounting and Economics (JAE)).

The papers by Ittner and Larcker (2001) and Zimmerman (2001) that appeared in JAE are likely one of the most familiar exchanges regarding management accounting research in the open literature. Zimmerman (2001) takes issue with the body of management accounting research and proposes the use of economic theories rather than alternative social science theories to view reality. After this exchange there was a burst of journal special issues (e.g., European Accounting Review (EAR) 2002, and Critical Perspectives on Accounting (CPA) 2008) and stand-alone papers on alternative approaches to management accounting research. The papers, mainly written by non-U.S. authors and appearing in non-U.S. journals, tout the benefits of alternative approaches to management accounting research and call for more respect and status in the broader academic community, as foreshadowed by Shillinglaw (1989). 
The 2010's. Eighteen papers in our sample have been written on the topic of diversity in just the first three years of the current decade. Two were written by U.S. academics and only one appeared in a U.S. based journal. A Management Accounting Research (MAR) special issue in 2010 includes nine papers and has two separate but related sections; one section on the relationship of theory and practice and one section on exploring paradigms as they relate to management accounting research. A 2012 special issue of $C P A$ includes four papers addressing the state of qualitative management accounting research and its relationship to the more dominant positivist quantitative research. A 2012 Qualitative Research in Accounting and Management ( $Q R A M)$ special issue includes 4 papers that discuss the role of qualitative methods in the practical relevance of management accounting research.

After forty-plus years of discussion and debate, Anthony's (1972) call for diversity came full circle in Merchant's (2013) acceptance speech for the 2013 Lifetime Contribution to Management Accounting award. A sense of déjà vu is apparent in Merchant's concern that management accounting, especially in the U.S., is in a downward spiral.

Other Notable Elements in the Data. The pattern of author affiliation and journal affiliation is notable and deserves mention. Table 1 presents the number and percentage of articles for the entire 40-year period by author (U.S. and non-U.S.) and journal affiliation (U.S. and non-U.S.). Non-U.S. authored papers are published almost exclusively in non-U.S. journals (92\%) while U.S. authored papers appear relatively frequently in non-U.S. journals (30\%). Interestingly, there are no papers written on the topic of diversity co-authored by U.S. and nonU.S. authors. Merchant and Van der Stede (2006) is the only possible exception. However, Van der Stede was at a U.S. school at the time so he is classified as a U.S. author.

---Insert Table 1 about here-- 


\section{Discussion}

The 40-plus year discourse on diversity in research methods has hopefully enriched our understanding of theories, paradigms, and methods in the management accounting academic field. The discussion has facilitated a growth of management accounting research in both its applicability to practice and the understanding of the generation and maturation of management accounting processes. The seed article by Anthony (1972) was not published in an accounting journal. Perhaps Anthony was trying to appeal to a larger audience and chose Sloan Management Review for that reason. Alternatively, what accounting journal in 1972 would have been a likely venue for Anthony's article? In our view, evidence of progress or at least a redefinition of the management accounting research milieu is the many major journals now available to management accounting academics in which to openly discuss these issues. ${ }^{1}$ However, even with more outlets, the division or compartmentalization of U.S. and non-U.S. authors and journals persists, as evidenced in Table 1.

The literature indicates that non-U.S. management accounting researchers responded to Anthony's call for research diversity by discussing and utilizing a diverse set of theories, paradigms, and methods. Non-U.S. authors expended much energy after 2000 trying to convince the global management accounting research community of the need for diversity in the tools necessary to conduct research. This effort may have provided an additional surge to their goal of improving their own sense of value within the global management accounting research community, as well as reinforcing claims for research diversity.

Nevertheless, the management accounting research community after 2000 to the present by and large acknowledges and accepts the need for research diversity (e.g., see Birnberg, 2004). Specific examples of the acknowledgement and acceptance of research diversity among U.S. and

\footnotetext{
${ }^{1}$ Hwang and $\mathrm{Wu}(2006)$ discuss the impact of additional publication outlets over the 1991 to 2000 period.
} 
non-U.S. scholars of management accounting are, for example, evident in: (1) the list of research papers presented at both the Management Accounting Section Research and Case Conferences and the Global Management Accounting Research Symposiums, (2) the elected leadership of the Management Accounting Section of the American Accounting Association, and (3) the organizers of and the programs of the Management Accounting Section's Doctoral Consortiums.

As a global community, management accounting researchers have grown to appreciate and accept research diversity, the importance of being relevant to practice, and having access to more journals,. However, there is at least some evidence that the opportunity to publish diverse research in top journals today is not very different from 1972, particularly in the U.S. The papers by Anthony (1972) and Merchant (2010, 2013) provide interesting snapshots of the beginning and end of the period. Merchant (2010) suggests that the myopic view of what constitutes good management accounting research in the U.S. is much the same as Anthony saw in 1972 and, in Merchant's opinion, that view will not broaden in the short term. U.S. management accounting research is by and large premised upon an objective reality that exists independent of any observer. This devotion to a nomothetic view of the world to the exclusion of other perspectives is part of the value structure in U.S. business schools for all the reasons given by Merchant (2010). The implication of that underlying value structure can be seen in the narrowness of the course work in doctoral programs that have all but eliminated the study of diverse research methods. Merchant (2010) argues that eventually this will change, although we have our doubts such is the extent of embedding of this nomothetic U.S. approach. Until then, however, he highlights the opportunity for non-U.S. business schools to become the leaders in management accounting research. 
Management accounting research needs knowledgeable specialists who can competently execute diverse research models. Other authors have recognized that preferences and biases are expressed in the form of specialization on particular topics and that publication outlets exist to address specialization and focus (e.g., Lukka \& Kasanen 1996). The management accounting research community could look to U.S. academics as the group that will originate nomothetic contributions. Viewing the U.S. research environment from this specialist perspective allows U.S. academics to produce work that is valued by the broader U.S. accounting research community, thereby supporting the career of the individual researcher. Not only will the U.S. accounting research community more readily accept the nomothetic research but also the work should be more readily publishable in top U.S. academic accounting journals. Additionally, this specialized research contributes to the broader management accounting knowledge base.

To balance the constraints on U.S. academics and provide the opportunity for leadership, non-U.S. academics have the liberty of using diverse theories, paradigms, and methods. While there are some universities which religiously follow the myopic U.S. perspective on management accounting research, a broader spectrum and a diversity can be seen in many research-oriented accounting departments outside of the U.S. Especially over the last two decades, there has been considerable growth and spread in the amount of alternative accounting research (Baxter and Chua, 2003) being undertaken in particular across Europe and Australasia.

Our sense of why alternative management accounting research has been allowed to flourish, and even promoted, outside of the U.S. can be linked to Merchant's (2013) notion of value structures. More specifically, business schools and accounting departments in non-U.S. settings have, in general, been subject to a far less strict, or possibly restrictive, value systems than in the U.S. This is not to say that the U.S. approach does not exist outside the U.S.; there are 
well-known non-U.S. institutions which are predominantly rooted in nomothetic methodologies. Regardless, in our view there tends to be a greater willingness at non-U.S. universities to build accounting departments that are more eclectic and where diversity is part of the expected norm among both faculty and in $\mathrm{PhD}$ programs.

However, the primary measure for academic quality in academic institutions remains journal rankings, regardless of an institution's location. The challenge for researchers who do not adopt a nomothetic view has been that their main target journals, which are primarily non-U.S., tend to be sparsely represented in the higher echelons of the principal journal rankings. While there may be some relatively local success for some journals (e.g., $A A A J$ currently has top ranking in Australia), only $A O S$ has been awarded highest ranking on a consistent basis. Yet $A O S$ is not a top-ranked journal at some U.S. institutions. Rankings tend to elevate U.S. accounting journals to the highest level, or at least one of the higher levels. Journal rankings can also have wider impact on the research activity and overall status of an accounting department (e.g., possible influence on the quality of $\mathrm{PhD}$ applications and the impact on the relative success of attaining external grants and other funds).

In the non-U.S. academic environment, it is difficult to predict how things might evolve from here, although some potentially significant change is probably likely. Higher education is undergoing significant change, on a global scale. Changes in the respective funding structures, new and changing competitive pressures and markets, and new technologically-fuelled programs and modes of delivery are but a few of the drivers. But there is probably one thing that we can predict with a degree of confidence. That is, it seems highly unlikely that all universities that are currently engaged in management accounting research will remain engaged. And, if this turns out to be the case, it will be ever more important for diversity and eclecticism to continue to 
thrive in non-U.S. institutions - if diversity and eclecticism is valued. However, for this to happen, we suspect that much will depend on the strategies of business school deans of non-U.S. institutions, as well as the (re-)composition of key journal rankings.

Importantly, the efforts of those who use and promote alternative management accounting research may appear to be simply an attempt to create a justification for a favored approach to compete with a nomothetic perspective that underlies what is called the mainstream approach. However, our interpretation of the situation is that non-U.S. researchers have scant issue with the nomothetic perspective per se; we find the nomothetic perspective is generally held as a welcome and necessary contribution to the overall diversity in our field. The issue is that when the U.S. perspective has such an influence on fundamental levers within the global system, in particular a domination of top journal rankings, it is probably unsurprising that researchers who do not have this perspective proactively seek to improve their value. In so doing, this is not an onslaught per se on U.S.-style management accounting research, but rather an attempt to articulate and enhance the perceived value of alternative research. As mentioned above, the behavior is more understandable in the context of how important journal rankings have now become, and the impact that rankings can eventually exert on such emotional and personal matters as promotion, salaries, and tenure.

As noted, the discussion in the literature refers to a mainstream that does not accept research diversity or relevance to practice. However, management accounting researchers behave in ways that admits of and supports the diversity, so the mainstream is really not management accounting researchers. Some management accounting researchers appear to be justifying our diversity to the U.S. accounting researchers who are not management accounting researchers. The U.S. non-management accounting researchers by and large produce and are 
evaluated with the expectation that the research is based on an objective reality that exists independent of the observer (i.e., the nomothetic perspective). Producing work based on this perspective is not a fault. What is at fault is the rejection of alternative perspectives.

As Merchant (2010) suggests, the relative narrowness of acceptable research methods in the U.S. creates the opportunity for non-U.S. management accounting researchers and journals to take the lead. For the foreseeable future, the narrow definition of good management accounting research and what is publishable in the U.S. will not foster, by itself, the diversity that the management accounting research community argues it is seeking. The expected and normed ways are far too embedded to expect any change to the U.S. situation in the foreseeable future. The underlying value structure continues to be reinforced by business school administration and faculty buy-in and by the editorial teams who control journal entry. If the management accounting research community is to achieve diversity, non-U.S. researchers and journals must provide the necessary breadth in terms of research theory, paradigm, method, and relevance to practice. The breadth will likely be in the guise of ideographic research (i.e., premised upon a reality defined in terms of interaction and experience). As we have argued, whether or not this will actually happen will likely depend to some degree on the short-to-medium term strategies of non-U.S. deans of business schools and the overall leanings of key journal rankings.

As Hopwood (2008a) suggests, the risk to management accounting research is that European and other non-U.S. business schools and management accounting researchers adopt the current U.S. model or that the non-U.S. management accounting research community places high and disproportionate value on publishing in U.S. based journals. This appears quite conceivable given the growing pressure to publish in highest-ranked journals. If the status quo maintains, we 
would expect a stifling of research diversity and a focusing of attention on nomothetic research with a limited research focus.

On the other hand, we might try to challenge these deep-rooted and potentially quite serious issues rooted in the U.S. That is, if it were possible to promote the argument that there is a need to change the structures underpinning what is valued in the U.S. management accounting research community, then conducting management accounting research that is diverse in nature would be seen in a far different and positive light. And, if the body of resulting work is sound then the research diversity and focus would provide prima facie evidence of the validity of the approach. Or, put another way, the evidence would be such that a logical positivist argument consistent with the nomothetic approach could be made for the validity of the management accounting researchers' diversity. Until implementing the strategy produces the evidence, there seems little chance of such change in the near future, when there is no obvious incentive for those identified as the mainstream group of accounting researchers to change. 


\section{References}

Ahrens,T., 2008. Overcoming the subjective-objective divide in management accounting research. Accounting, Organizations and Society 33(2-3), 292-297.

Ahrens, T., Chapman, C., 2006. Doing qualitative research in management accounting: Positioning data to contribute to theory. Accounting, Organizations and Society 31, 819-841.

Ahrens, T., Becker, A., Burns, J., Chapman, C., Granlund, M., Habersam, M., Hansen, A., Khalifa, R., Malmi, T., Mennicken, A., Mikes, A., Panozzo, F., Piber, M., Quattrone, P., Scheytt, T., 2008. The future of interpretive accounting research - A polyphonic debate. Critical Perspectives on Accounting 19, 840-866.

Anthony, R., 1972. Management accounting for the future. Sloan Management Review 13, $17-$ 34.

Anthony, R., 1989. Reminiscences about management accounting. Journal of Management Accounting Research 1, 1-20.

Armstrong, P., 2008. Calling out for more: Comment on the future of interpretive accounting research. Critical Perspectives on Accounting 19, 867-879.

Baldvinsdottir, G., Mitchell, F., Norreklit, H., 2010. Issues in the relationship between theory and practice in management accounting. Management Accounting Research 21, 79-82.

Baxter, J. and Chua, W. F., 2003. Alternative management accounting research. Accounting, Organizations and Society 28(2-3), 97-126.

Baxter, J., Boedker, C., Chua, W.F., 2008. The future(s) of interpretive accounting research - A polyphonic response from beyond metropolis. Critical Perspectives on Accounting 19, 880-886.

Birnberg, J., 1992. Management accounting: Yet another retrospective. Advances in management Accounting 1, 1-19.

Birnberg, J., 1999. Management accounting practice and research as we end the twentieth century. Advances in Management Accounting 8, 1-26.

Birnberg, J., 2004. Expanding our frontiers: management accounting research in the next decade. Advances in Management Accounting 8, 1-26.

Birnberg, J., 2009. The case for post-modern management accounting: Thinking outside the box. Journal of Management Accounting Research 21, 3-18.

ter Bogt, H., van Helden, J., 2012. The practical relevance of management accounting research and the role of qualitative methods therein. Qualitative Research in Accounting and Management 9(3). 
ter Bogt, H., van Helden, J., 2012. The practical relevance of management accounting research and the role of qualitative methods therein: the debate continues. Qualitative Research in Accounting and Management 9(3), 265-273.

Broadbent, J., 2012. Commentary on Parker; Groundhog day and optimism. Critical Perspectives on Accounting 23, 71-77.

Chapman, C., 2008. We are not alone: Qualitative management accounting research - rationale, pitfalls and potential. Qualitative Research in Accounting and Management 5(3), 247-252.

Chua, W.F., Mahama, H., 2012. On theory as a deliverable and its relevance in 'policy' arenas. Critical Perspectives on Accounting 23, 78-82.

Cooper, D., 2008. Is there a future for interpretive accounting research? Critical Perspectives on Accounting 19, 837-839.

Cooper, D., Hopper, T., 2007. Critical theorizing in management accounting research. Handbook of Management Accounting Research, 207-245.

Cooper, D., Morgan, G., 2008. Case study research in accounting. Accounting Horizons 22, 159178.

Davila, T., Oyon, D., 2008. Cross-paradigm collaboration and the advancement of management accounting knowledge. Critical Perspectives on Accounting 19, 887-893.

Dillard, J., 2008. A political base of the polyphonic debate. Critical Perspectives on Accounting 19, 894-900.

Epstein, M. 1992. Introduction: As management accounting moves toward 2000. Advances in Management Accounting 1, xi-xv.

Flamholtz, E. 1992. Relevance regained: Management accounting -- past, present, and future. Advances in Management Accounting 1, 21-34.

van Helden, G., Aardema, H., ter Bogt, H., Groot, T., 2010. Knowledge creation for practice in public sector management accounting by consultants and academics: Preliminary findings and directions for future research. Management Accounting Research 21, 83-94.

Hopper, T., Storey, J., Willmott, H., 1987. Accounting for accounting: Towards the development of a dialectical view. Accounting, Organizations and Society 12(5), 437-456.

Hopwood, A.,1983. On trying to study accounting in the contexts in which it operates. Accounting, Organizations and Society 8(2-3), 287-305. 
Hopwood, A., 2002. If there only were simple solutions but there aren't: Some reflections on Zimmerman's critique on empirical accounting research. European Accounting Review 11(2), 777-785.

Hopwood, A., 2008a. Management accounting research in a changing world. Journal of Management Accounting Research 20, 3-13.

Hopwood, A., 2008b. Changing pressures on the research process: On trying to research in an age when curiosity is not enough. European Accounting Review 17(1), 87-96.

Horngren, C., 1989. Cost and management accounting: Yesterday and today. Journal of Management Accounting Research 1, 21-32.

Hwang, N. R., Wu, D., 2006. Has the emergence of the specialized journals affected management accounting research paradigms? Advances in Management Accounting 15, 143168.

Ittner, C., Larcker, D., 2001. Assessing empirical research in managerial accounting: A valuebased management perspective. Journal of Accounting and Economics 32, 349-410.

Ittner, C., Larcker, D., 2002. Empirical management accounting: Are we just describing management consulting practice? European Accounting Review 11(4), 787-794.

Kakkuri-Knuuttila, M.-L., Lukka, K., Kuorikoski, J., 2008a. No premature closures of debates, please: A response to Ahrens. Accounting, Organizations and Society 33(2-3), 267-291.

Kakkuri-Knuuttila, M.-L., Lukka, K., Kuorikoski, J., 2008b. No premature closures of debates, please: A response to Ahrens. Accounting, Organizations and Society 33(2-3), 298-301.

Kaplan, R., 1983. Measuring manufacturing performance: A new challenge for managerial accounting research. The Accounting Review 58(4), 686-705.

Kaplan, R., 1984. The evolution of management accounting systems. The Accounting Review 59(3), 390-418.

Kaplan, R., 1986. The role for empirical research in management accounting. Accounting, Organizations and Society 11(4-5), 429-452.

Kaplan, R., 1993. Research opportunities in management accounting. Journal of Management Accounting Research 5, 1-14.

Kasanen, E., Lukka, K., Siitonen, A., 1993. The constructive approach in management accounting research. Journal of Management Accounting Research 5, 243-264. 
Lillis, A., 2008. Qualitative management accounting research: Rationale, pitfalls and potential: A comments on Vaivio (2008). Qualitative Research in Accounting and Management 5(3), 239246.

Llewelyn, S., 2003. What counts as 'theory' in qualitative management and accounting research? Accounting, Auditing and Accountability Journal 16(4), 662-708.

Locke, J., Lowe, A., 2008. Evidence and implications of multiple paradigms in accounting knowledge production. European Accounting Review 17(1), 161-191.

Luft, J., Shields, M.D., 2002. Zimmerman's contentious conjectures: Describing the present and prescribing the future of empirical management accounting research. European Accounting Review 11(4), 795-803.

Lukka, K., 2010. The roles and effects of paradigms in accounting research. Management Accounting Research 21, 110-115.

Lukka, K., Kasanen, E., 1996. Is accounting a global or a local discipline? Evidence from major research journals. Accounting, Organizations and Society 21(7-8), 755-773.

Lukka, K., Mouritsen, J., 2002. Homogeneity or heterogeneity of research in management accounting. European Accounting Review 11(4), 805-811.

Malmi, T., 2010. Reflections on paradigms in action accounting research. Management Accounting Research 21, 121-123.

Malmi, T., Granlund, M., 2009a. In search of management accounting theory. European Accounting Review 18(3), 597-620.

Malmi, T., Granlund, M., 2009b. Agreeing on problems, where are the solutions? A reply to Quattrone. European Accounting Review 18(3), 631-639.

van der Meer-Kooistra, J., Vosselman, E., 2012. Research paradigms, theoretical pluralism and the practical relevance of management accounting knowledge. Qualitative Research in Accounting and Management 9(3), 245-254.

Merchant, K., 2008. Why interdisciplinary accounting research tends not to impact most North American academic accountants. Critical Perspectives on Accounting 19, 901-908.

Merchant, K., 2010. Paradigms in accounting research: A view from North America. Management Accounting Research 21, 116-120.

Merchant, K., 2013. Looking back, looking forward. Journal of Management Accounting Research 25, 65-70. 
Merchant, K., Van der Stede, W., 2006. Field-based research in accounting: Accomplishments and prospects. Behavioral Research in Accounting 18, 117-134.

Mitchell, F., 2002. Research and practice in management accounting: Improving integration and communication. European Accounting Review 11(2), 277-289.

Modell, S., 2010. Bridging the paradigm divide in management accounting research: The role of mixed methods approaches. Management Accounting Research 21, 124-129.

Parker, L., 2008. Interpreting interpretive accounting research. Critical Perspectives on Accounting 19, 909-914.

Parker, L., 2010. Qualitative management accounting research: Assessing deliverables and relevance. Critical Perspectives on Accounting 23, 54-70.

Quattrone, P., 2009. We have never been post-modern: On the search of management accounting theory. European Accounting Review 18(3), 621-630.

Richardson, A., 2012. Paradigms, theory and management accounting practice: A comment on Parker (forthcoming) "Qualitative management accounting research: Assessing deliverables and relevance”. Critical Perspectives on Accounting 23, 83-88.

Scapens, R. W., 1994. Never mind the gap: towards an institutional perspective on management accounting practices. Management Accounting Research 5(3-4), 301-21.

Scapens, R. W., Burns, J., Ezzamel, M. and Baldvinsdottir, G., 2003. "The future direction of UK management accounting practice”. CIMA/Elsevier.

Scapens, R. W., 2006. Understanding management accounting practices: A personal journey. The British Accounting Review 38, 1-30.

Scapens, R. W., 2008. Seeking relevance of interpretive research: A contribution to the polyphonic debate. Critical Perspectives on Accounting 19, 915-919.

Scapens, R. W., Bromwich, M., 2010. Practice, theory and paradigms. Management Accounting Research 21, 77-78.

Seal, W., 2010. Managerial discourse and the link between theory and practice: From ROI to value-based management. Management Accounting Research 21, 95-109.

Seal, W., 2012. Some proposals for impactful management control research. Qualitative Research in Accounting and Management 9(3), 228-244.

Shillinglaw, G.,1989. Managerial cost accounting: present and future. Journal of Management Accounting Research 1, 33-46. 
Spicer, B., 1992. The resurgence of cost and management accounting: A review of some recent developments in practice, theories and case research methods. Management Accounting Research 3, 1-37.

Vaivio, J., 2008. Qualitative management accounting research: Rationale, pitfalls and potential. Qualitative Research in Accounting and Management 5(1), 64-86.

Vaivio, J., Siren, A., 2010. Insights into method triangulation and "paradigms" in interpretive management accounting research. Management Accounting Review 21(2), 130-141.

Williams, P., Jenkins, J., Ingraham, L., 2006. The winnowing away of behavioral accounting research in the US: The process for anointing academic elites. Accounting, Organizations and Society 31(8), 783-818.

Willmott, H., 2008. Listening, interpreting, commending: A commentary on the future of interpretive accounting research. Critical Perspectives on Accounting 19, 920-925.

Zimmerman, J., 2001. Conjectures regarding empirical managerial accounting research. Journal of Accounting and Economics 32, 411-427. 

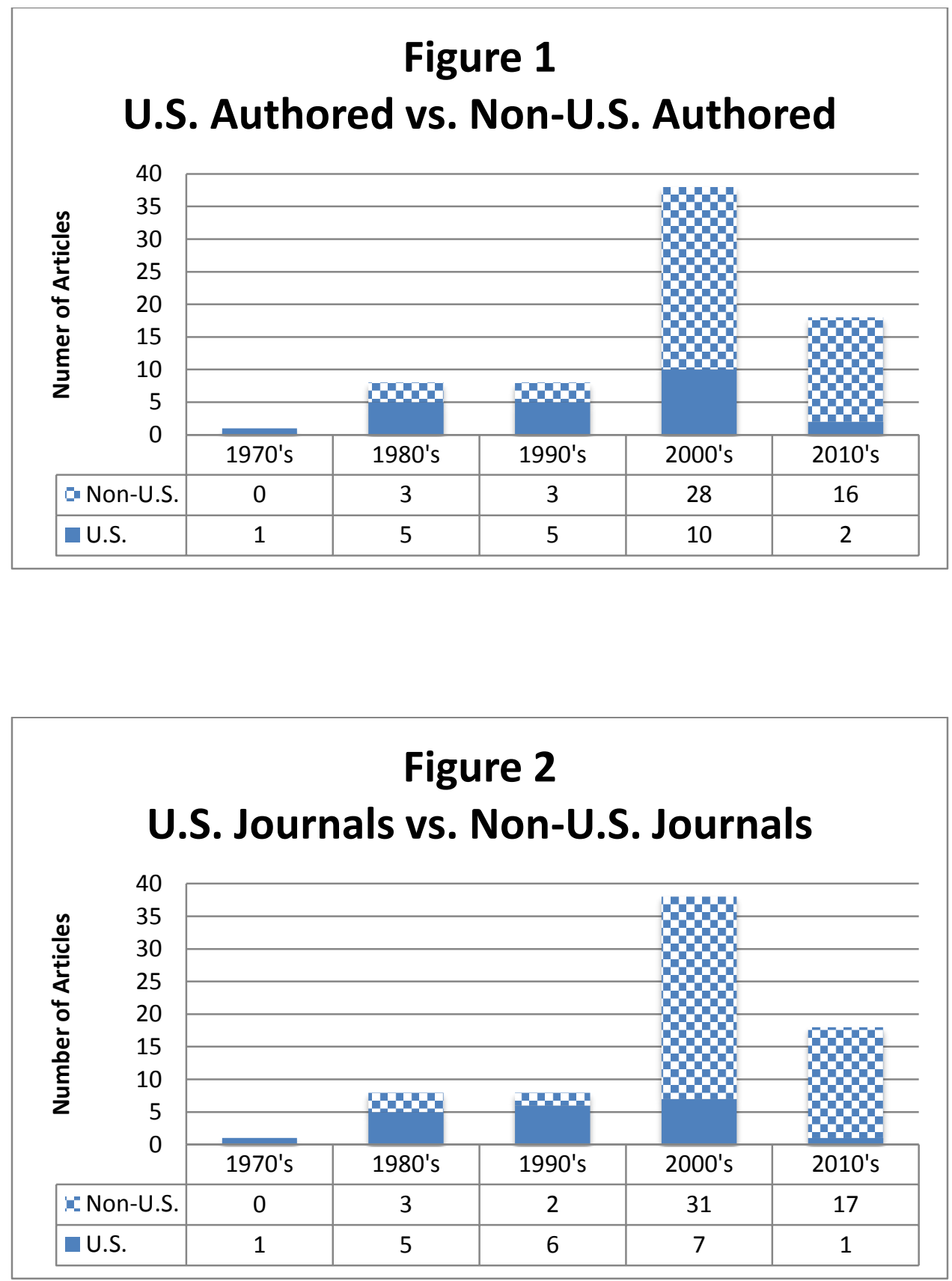
Table 1

Distribution of U.S. and Non-U.S Affiliation of Articles and Journals Reviewed

\begin{tabular}{rrrrr}
\hline \multicolumn{5}{c}{ Journals } \\
\hline \\
& U.S. & U.S. & Non-U.S. & Total \\
& & 16 & 7 & 23 \\
& Non-U.S. & $70 \%$ & $30 \%$ & $100 \%$ \\
& & 4 & 46 & 50 \\
& Total & $8 \%$ & $92 \%$ & 73 \\
\hline
\end{tabular}




\section{Appendix 1}

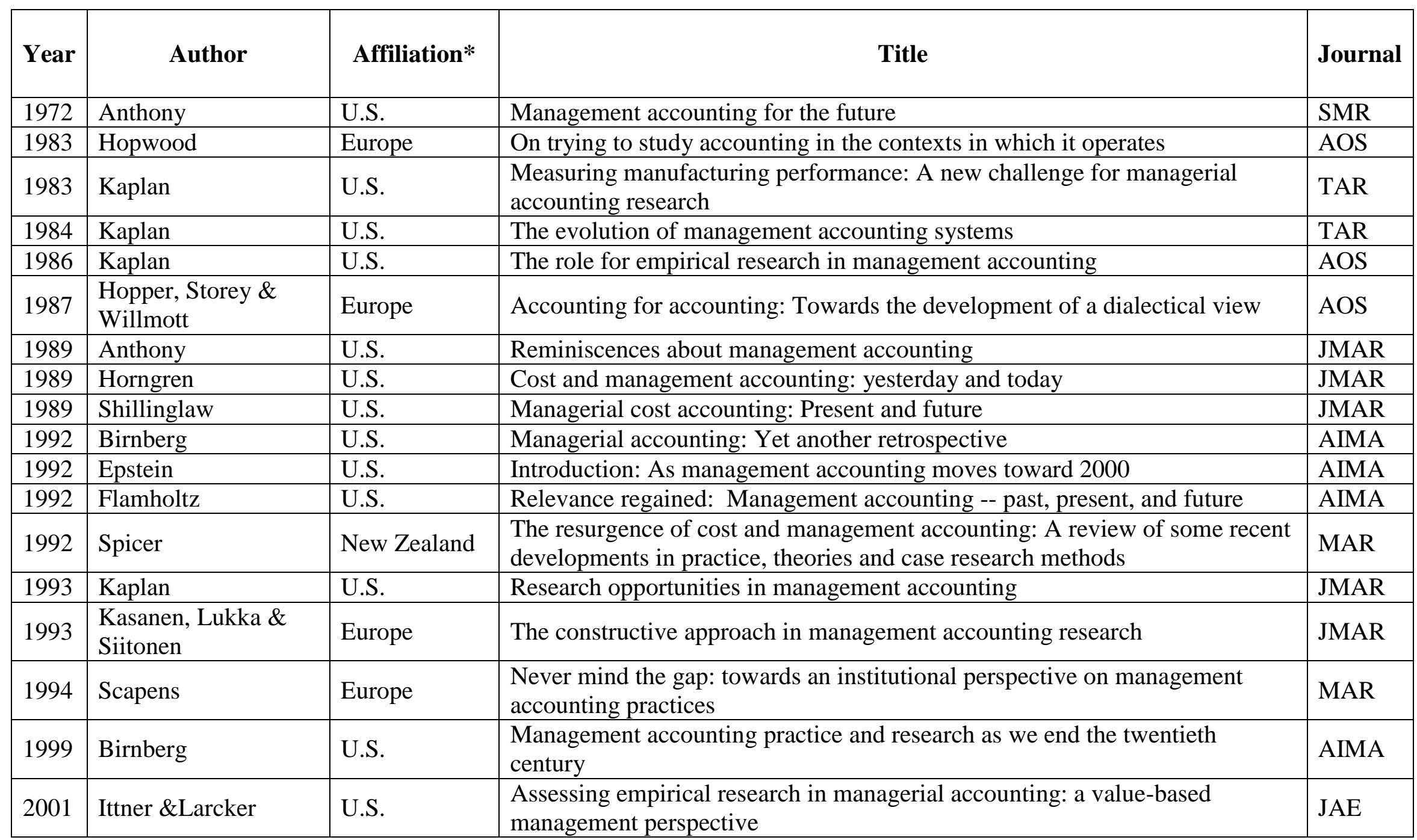




\begin{tabular}{|c|c|c|c|c|}
\hline 2001 & Zimmerman & U.S. & Conjectures regarding empirical managerial accounting research & JAE \\
\hline 2002 & Ittner \& Larcker & U.S. & $\begin{array}{l}\text { Empirical management accounting research: are we just describing } \\
\text { management consulting practice? }\end{array}$ & EAR \\
\hline 2002 & Luft \& Shields & U.S. & $\begin{array}{l}\text { Zimmerman's contentious conjectures: Describing the present and prescribing } \\
\text { the future of empirical management accounting research }\end{array}$ & EAR \\
\hline 2002 & Lukka \& Mouritsen & Europe & Homogeneity or heterogeneity of research in management accounting & EAR \\
\hline 2003 & Llewelyn & Europe & What counts as 'theory' in qualitative management and accounting research? & AAAJ \\
\hline 2004 & Birnberg & U.S. & Expanding our frontiers: Management accounting research in the next decade & AIMA \\
\hline 2006 & Ahrens \& Chapman & Europe & $\begin{array}{l}\text { Doing qualitative research in management accounting: positioning data to } \\
\text { contribute to theory }\end{array}$ & AOS \\
\hline 2006 & $\begin{array}{l}\text { Merchant \& van der } \\
\text { Stede }\end{array}$ & U.S. & Field-based research in accounting: accomplishments and prospects & BRIA \\
\hline 2007 & Cooper \& Hopper & $\begin{array}{l}\text { Canada and } \\
\text { Europe }\end{array}$ & Critical theorizing in management accounting research & HMAR \\
\hline 2008 & Ahrens & Europe & $\begin{array}{l}\text { Overcoming the subjective--objective divide in management accounting } \\
\text { research }\end{array}$ & AOS \\
\hline 2008 & $\begin{array}{l}\text { Ahrens, Becker, } \\
\text { Burns, Chapman, } \\
\text { Granlund, Habersam, } \\
\text { Hansen, Khalifa, } \\
\text { Malmi, Mennicken, } \\
\text { Mikes, Panozzo, } \\
\text { Piber, Quattrone \& }\end{array}$ & Europe & The future of interpretive accounting research - A polyphonic debate & CPA \\
\hline
\end{tabular}




\begin{tabular}{|c|c|c|c|c|}
\hline & Scheytt & & & \\
\hline 2008 & Armstrong & Europe & $\begin{array}{l}\text { Calling out for more: Comment on the future of interpretive accounting } \\
\text { research }\end{array}$ & CPA \\
\hline 2008 & $\begin{array}{l}\text { Baxter, Boedker \& } \\
\text { Chua }\end{array}$ & Australia & $\begin{array}{l}\text { The future(s) of interpretive accounting research - A polyphonic response } \\
\text { from beyond the metropolis }\end{array}$ & CPA \\
\hline 2008 & Chapman & Europe & $\begin{array}{l}\text { We are not alone: Qualitative management accounting research - rationale, } \\
\text { pitfalls and potential }\end{array}$ & QRAM \\
\hline 2008 & Cooper & Canada & Is there a future for interpretive accounting research? & CPA \\
\hline 2008 & Cooper \& Morgan & Canada & Case study research in accounting & $\mathrm{AH}$ \\
\hline 2008 & Davila \& Oyon & Europe & $\begin{array}{l}\text { Cross-paradigm collaboration and the advancement of management } \\
\text { accounting knowledge }\end{array}$ & $\mathrm{CPA}$ \\
\hline 2008 & Dillard & U.S. & A political base of the polyphonic debate & CPA \\
\hline 2008 & Hopwood & Europe & Management accounting research in a changing world & JMAR \\
\hline 2008 & Hopwood & Europe & $\begin{array}{l}\text { Changing pressures on the research process: on trying to research in an age } \\
\text { when curiosity is not enough }\end{array}$ & EAR \\
\hline 2008 & $\begin{array}{l}\text { Kakkuri-Knuuttila, } \\
\text { Lukka \& Kuorikoski }\end{array}$ & Europe & No premature closures of debates, please: a response to Ahrens & AOS \\
\hline 2008 & $\begin{array}{l}\text { Kakkuri-Knuuttila, } \\
\text { Lukka \& Kuorikoski }\end{array}$ & Europe & $\begin{array}{l}\text { Straddling between paradigms: A naturalistic philosophical case study on } \\
\text { interpretive research in management accounting }\end{array}$ & AOS \\
\hline 2008 & Lillis & Australia & $\begin{array}{l}\text { Qualitative management accounting research: Rationale, pitfalls and } \\
\text { potential: A comments on Vaivio (2008) }\end{array}$ & QRAM \\
\hline 2008 & Locke \& Lowe & Europe & $\begin{array}{l}\text { Evidence and implications of multiple paradigms in accounting knowledge } \\
\text { production }\end{array}$ & EAR \\
\hline 2008 & Merchant & U.S. & $\begin{array}{l}\text { Why interdisciplinary accounting research tends not to impact most North } \\
\text { American academic accountants }\end{array}$ & CPA \\
\hline 2008 & Parker & Australia & Interpreting interpretive accounting research & CPA \\
\hline 2008 & Scapens & Europe & $\begin{array}{l}\text { Seeking the relevance of interpretive research: A contribution to the } \\
\text { polyphonic debate }\end{array}$ & CPA \\
\hline 2008 & Vaivio & Europe & Qualitative management accounting research: rationale, pitfalls and potential & QRAM \\
\hline 2008 & Willmott & Europe & Listening, interpreting, commending: a commentary on the future of & CPA \\
\hline
\end{tabular}




\begin{tabular}{|c|c|c|c|c|}
\hline & & & interpretive accounting research & \\
\hline 2009 & Birnberg & U.S. & The case for post-modern management accounting: Thinking outside the box & JMAR \\
\hline 2009 & Malmi \& Granlund & Europe & In search of management accounting theory & EAR \\
\hline 2009 & Malmi \& Granlund & Europe & Agreeing on problems, where are the solutions? A reply to Quattrone & EAR \\
\hline 2009 & Quattrone & Europe & $\begin{array}{l}\text { We have never been post-modern': On the search of management accounting } \\
\text { theory }\end{array}$ & EAR \\
\hline 2010 & $\begin{array}{l}\text { Baldvinsdottir, } \\
\text { Mitchell \& Norreklit }\end{array}$ & Europe & $\begin{array}{l}\text { Issues in the relationship between theory and practice in management } \\
\text { accounting }\end{array}$ & MAR \\
\hline 2010 & $\begin{array}{l}\text { van Helden, } \\
\text { Aardema, ter Bogt \& } \\
\text { Groot }\end{array}$ & Europe & $\begin{array}{l}\text { Knowledge creation for practice in public sector management accounting by } \\
\text { consultants and academics: Preliminary findings and directions for future } \\
\text { research }\end{array}$ & MAR \\
\hline 2010 & Lukka & Europe & The roles and effects of paradigms in accounting research & MAR \\
\hline 2010 & Malmi & Europe & Reflections on paradigms in action accounting research & MAR \\
\hline 2010 & Merchant & U.S. & Paradigms in accounting research: A view from North America & MAR \\
\hline 2010 & Modell & Europe & $\begin{array}{l}\text { Bridging the paradigm divide in management accounting research: The role } \\
\text { of mixed methods approaches }\end{array}$ & MAR \\
\hline 2010 & $\begin{array}{l}\text { Scapens \& } \\
\text { Bromwich }\end{array}$ & Europe & Practice, theory and paradigms & MAR \\
\hline 2010 & Seal & Europe & $\begin{array}{l}\text { Managerial discourse and the link between theory and practice: From ROI to } \\
\text { value-based management }\end{array}$ & MAR \\
\hline 2010 & Vaivio \& Siren & Europe & $\begin{array}{l}\text { Insights into method triangulation and "paradigms" in interpretive } \\
\text { management accounting research }\end{array}$ & MAR \\
\hline 2012 & $\begin{array}{l}\text { ter Bogt \& van } \\
\text { Helden }\end{array}$ & Europe & $\begin{array}{l}\text { The practical relevance of management accounting research and the role of } \\
\text { qualitative methods therein. }\end{array}$ & QRAM \\
\hline 2012 & $\begin{array}{l}\text { ter Bogt \& van } \\
\text { Helden }\end{array}$ & Europe & $\begin{array}{l}\text { The practical relevance of management accounting research and the role of } \\
\text { qualitative methods therein: the debate continues }\end{array}$ & QRAM \\
\hline 2012 & Broadbent & Europe & Commentary on Parker: Groundhog Day and optimism & CPA \\
\hline 2012 & Chua \& Mahama & lia & On theory as a deliverable and its relevance in 'policy' arenas & CPA \\
\hline 2012 & van der Meer- & Europe & 2012. Research paradigms, theoretical pluralism and the practical relevance & QRAM \\
\hline
\end{tabular}




\begin{tabular}{|c|c|c|c|c|}
\hline & $\begin{array}{l}\text { Kooistra \& } \\
\text { Vosselman } \\
\end{array}$ & & of management accounting knowledge & \\
\hline 2012 & Parker & Australia & $\begin{array}{l}\text { Qualitative management accounting research: Assessing deliverables and } \\
\text { relevance }\end{array}$ & CPA \\
\hline 2012 & Richardson & Canada & $\begin{array}{l}\text { Paradigms, theory and management accounting practice: A comment on } \\
\text { Parker (forthcoming) "Qualitative management accounting research: } \\
\text { Assessing deliverables and relevance" }\end{array}$ & $\mathrm{CPA}$ \\
\hline 2012 & Seal & Europe & Some proposals for impactful management control research & QRAM \\
\hline 2013 & Merchant & U.S. & Looking Back, Looking Forward & JMAR \\
\hline
\end{tabular}

* based on location of school listed in the published article

Notes: AAAJ - Accounting, Auditing and Accountability Journal

AIMA - Advance in Management Accounting

AH - Accounting Horizons

AOS - Accounting, Organizations and Society

BRIA - Behavioral Research in Accounting

BAR - The British Accounting Review

CPA - Critical Perspectives on Accounting

EAR - European Accounting Review

JAE - Journal of Accounting and Economics

JMAR - Journal of Management Accounting Research

HMAR - Handbook of Managerial Accounting Research

MAR - Management Accounting Research

QRAM - Qualitative Research in Accounting and Management

SMR - Sloan Management Review

TAR - The Accounting Review 